\title{
Morphometric Criteria \\ for Bioassay of Agonist and Antagonist Actions of Steroid Hormones on the Mammary Gland
}

\author{
A. HUFRIY*, E. KÖHLEROVÁ, J. ŠKARDA
}

Institute of Animal Physiology and Genetics, Czech Academy of Sciences, Prague 10-Uhříněves *Present address: Lviv State Agricultural University, 80381 Dubljani, Ukraine

Received March 28, 2003

Accepted September 22, 2003

\section{Abstract}

Hufriy A., Köhlerová E., Škarda J.: Morphometric Criteria for Bioassay of Agonist and Antagonist Actions of Steroid Hormones on the Mammary Gland. Acta Vet. Brno 2003, 72 : 483-491.

Previously it has been shown that measuring of the percent area of mammary fat pad occupied by mammary epithelial structures is a suitable parameter for bioassay estrogenicity and for the assessment of mixture effects of estrogenic agonists and antagonists. The purpose of the present study was to investigate how estradiol (E), progesterone (Prog) and E plus Prog dose dependently affect the number of terminal end buds (TEBs) and the number of ductal branchings in young intact (18-dayold) and adult gonadectomized male and female (OV-X, ovariectomized between 21-24 days of age; $\mathrm{OV}-\mathrm{X}) \mathrm{C} 3 \mathrm{H}$ mice and assess if the number of the TEBs and ductal branchings are suitable supplemental parameters for estrogenicity bioassay. The results demonstrate that in animals treated with $\mathrm{E}$ or E valerate (EV) a classic biphasic dose-response curve was obtained. The lower doses of E or EV (0.001-0.1 $\left.\mu \mathrm{g} . \mathrm{d}^{-1}\right)$ increased both the number of TEBs (mainly large buds) and ductal branchings, whereas the higher doses $\left(1\right.$ and $\left.10 \mu \mathrm{g} . \mathrm{d}^{-1}\right)$ were inhibitory. In young intact females doseresponse studies with Prog alone revealed that the number of TEBs and the degree of ductal banchings progressively increased from the dose of $125 \mu \mathrm{g} . \mathrm{d}^{-1}$ and reached a higher level than that achieved in animals treated with E alone. However, in adult OV-X females Prog increased number of small TEBs from dose $250 \mu \mathrm{g} . \mathrm{d}^{-1}$ but the increase in ductal branching was not significant. Both parameters were lower than those achieved in animals treated with E alone. Prog alone at high $\left(1000 \mu \mathrm{g} . \mathrm{d}^{-1}\right)$ dose only slightly increased number of TEBs in young intact males but had no effect on number of both TEBs in castrated males and on the number of ductal branchings in both young intact and adult castrated males. In young intact females treated with different doses $\left(0.001-10 \mu \mathrm{g} . \mathrm{d}^{-1}\right)$ E plus Prog $\left(500 \mu \mathrm{g} . \mathrm{d}^{-1}\right)$, the number of TEBs and the number of ductal branchings was not significantly different from that in animals treated with Prog alone. However, in OV-X females E plus Prog increased the number of both TEBs and ductal branchings when compared with OV-X females treated with Prog alone. In males E also synergized the effect of Prog in stimulation of both the number of TEBs and the number of ductal branchings. High dose $\left(10 \mu \mathrm{g} . \mathrm{d}^{-1}\right)$ of $\mathrm{E}$ in combination with Prog decreased number of both TEBs and ductal branchings in males and OV-X females.

Mice, mammary epithelium growth, estradiol, progesterone

There is considerable concern about the increasing incidence of endocrine-related cancers and deteriorating reproductive health in humans, wildlife and farm animals. Large number of natural and man-made chemicals with widely diverse chemical structure has the ability to mimic or inhibit the action of the endogenous steroid hormones by binding to and activating their receptors (Payne et al. 2000). This diversity makes it difficult to predict steroid hormone agonist and antagonist activities on structural bases or radioimmunoassay or radioreceptorassay. It is clear that characterization of agents as steroid hormone agonist or antagonist necessitates the integrated use of in vivo and in vitro assays. However, the critical objective is to detect chemicals that may be active in vivo, thereby taking into account bioavailability and metabolism of a substance in animals. The golden standard for detection

Address for correspondence:

Doc. MVDr. Josef Škarda, DrSc.

Institute of Animal Physiology and Genetics

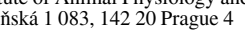

Czech Republic
Phone: +420267090505

Fax: +420 267090500

http://www.vfu.cz/acta-vet/actavet.htm 
of functional estrogenicity at this time is still the mouse uterine bioassay, precisely because it replicates a live situation and incorporates the effects of metabolism, serum binding, and pharmacokinetics (Korach and McLachlan 1995). However, this bioassay is not specific as the increase in uterine weight is stimulated not only by estrogens but also androgens (Neumann and Steinbeck 1974; Š karda 2002b). Moreover, the increase in uterine wet weight results not only from hyperplasia but also from water inbibition and hypertrophy (which is also produced by estrogen antagonist) (Clark et al. 1980). Thus, in vivo screening design should not consist of a single endpoint but rather several endpoints reflective to the mechanism involved in different organs in the same animal. Such tests would not be necessarily indicative of a specific mechanism of action, but capable of assessing overall function of the endocrine system (Ankley et al. 1998).

Recently we have developed a simple and reliable system for determination of steroid hormone agonist and antagonist activities in vivo in which stimulation and/or inhibition of growth of different organs (mammary gland, uterus, seminal vesicles and spleen) could be induced simultaneously in the same mouse with a single agent or a simple combination of agents (Škarda 2002abc, 2003). To evaluate mammary growth responses we determined the percent area of mammary fat pad occupied by mammary epithelial structures in mammary whole-mount preparations. Thus in contrast to uterotrophic assay this bioassay measures cell proliferation only. In the following experiments we used the degree of ductal branching and the number of terminal end buds (TEBs) at the terminus of ducts as a morphometric criterium of mammary growth, in response to estrogen and Prog.

\section{Materials and Methods}

Materials

2,2,2-tribromoethanol (Fluka Chemie AG, Buchs, Switzerland) and t-amylalcohol (Sigma-Aldrich, Prague, Czech Republic) were used for preparation of Avertin. Progesterone (Prog), 17 $\beta$-estradiol (E) were bought from Sigma-Aldrich. A long-acting steroid - estradiol valerate (EV; Neofollinß) was purchased from Biotika, Slovenská Lupča (Slovakia). Heavy-duty Kapak/Scotchpak heat sealable pouches (Stock No. 502) from KAPAK Corporation (Minneapolis, MN, U.S.A.) were gifts from Professor Evelyn M. Rivera, Michigan State University, East Lansing, U.S.A.). Oily vehicle (benzyl alcohol $24 \mathrm{~g}$, benzyl benzoate $242 \mathrm{~g}$, butylhydroxyanisole $2 \mathrm{~g}$, butylhydroxytoluene $2 \mathrm{~g}$, ethyl oleate $806 \mathrm{~g}$, ethanol $28 \mathrm{~g}$ ) was purchased from Spofa a. s. (Prague, Czech Republic).

Animals

Outbred C3H/Di mice were from our own colony. Animals were maintained on a $12 \mathrm{~h} \mathrm{light/12} \mathrm{h} \mathrm{dark} \mathrm{lighting}$ schedule, fed pelleted diet (TOP Velaz, Lysá nad Labem, Czech Republic). To minimize variation of the doseresponse relationship of injected hormones, all young animals were weighed at the age of 18 days and only animals weighing $8 \pm 1 \mathrm{~g}$ were randomly distributed into the treated groups.

Young intact (18 days of age) and adult gonadectomized (females were ovariectomized at 22-24 days of age; males were castrated at 30-35 days of age) mice were used. Gonadectomy was performed under Avertin anesthesia (Škarda 2001). Gonadectomy of the immature animals regresses mammary terminal end buds to form rudimentary TEBs or terminal ducts and arrests the further developments of mammary gland and uterus in females and seminal vesicles in males. Estrogens and progestins can reverse the changes induced by ovariectomy in females and induce growth of mammary rudiment in males. Testosterone and other androgens can reverse the changes induced in seminal vesicles by castration and inhibit E or E+Prog or norethindrone acetate stimulated growth of mammary rudiment (Škarda 2002 abc, 2003). Animals were subcutaneously injected $50 \mu l$ of oily vehicle (control) or a steroid hormone in oily vehicle for 10 or 15 days in females and males respectively. This period is long enough to mimic exposure to constant level of a steroid hormone agonist or antagonist or hormone mixtures for a significant phase of life much like that achieved in animals exposed to hormonally active xenobiotics.

Doses of hormones are expressed in mg per day per 11 or $13 \mathrm{~g}$ of body weight in young intact or per 21 or 24 $\mathrm{g}$ of body weight in adult gonadectomized females and males respectively. At the end of treatment and within 24 $\mathrm{h}$ of the last hormone administration, animals were killed and the first pair of inguinal mammary fat pads was removed for whole mount ( $\breve{S} \mathrm{k}$ arda 2001). In order to measure the degree of mammary ductal branching, junctions between ducts were counted on photographs of whole mount preparations. Small ducts or rudimentary branches and major ducts were counted equally. In addition, the number of end buds at the terminus of ducts was counted. Mammary fat pads of males that showed no detectable mammary gland were excluded from the data set.

All experimental procedures were conducted in compliance with the highest standards of humane animal care and approved by the Ethical Committee of the Institute of Animal Physiology and Genetics of the Academy of Sciences. 
Statistical analysis

The number of both ductal branching and end buds was sufficiently normally distributed so that parametric analysis could be used. All data represent means \pm S.E.M. Statistically significant difference was determined by ANOVA, followed by the Bonferroni test for individual comparisons of the mean. Differences were considered significant at $P \leq 0.05$.

\section{Results}

When the animals were injected with different doses of estrogens (E or EV 0.001-10 $\mu \mathrm{g} . \mathrm{d}^{-1}$ ), a classic biphasic dose-response curve was obtained both in young intact and adult castrated males and females (Table 1, 2, 3). The lower doses of E or EV $\left(0.001-0.1 \mu \mathrm{g} . \mathrm{d}^{-1}\right)$ increased the number of both TEBs and ductal branchings, whereas the higher doses $\left(1\right.$ and $\left.10 \mu \mathrm{g} \cdot \mathrm{d}^{-1}\right)$ were inhibitory.

Table 1

Effect of 173 estradiol (E), progesterone (Prog) and their combinations on the number of terminal end buds (TEBs) and ductal branchings of the first inguinal mammary gland in young intact and adult ovariectomized $(\mathrm{OV}-\mathrm{X})$ female $\mathrm{C} 3 \mathrm{H}$ mice

\begin{tabular}{|c|c|c|c|c|}
\hline \multirow{2}{*}{$\begin{array}{l}\text { Hormonal } \\
\text { treatment } \\
\left(\mu \mathrm{g} . \mathrm{d}^{-1}\right)\end{array}$} & \multicolumn{2}{|c|}{ Number of TEBs } & \multicolumn{2}{|c|}{$\begin{array}{l}\text { Number of ductal } \\
\text { branchings }\end{array}$} \\
\hline & Intact & OV-X & Intact & OV-X \\
\hline 0 & $18.3 \pm 1.2^{\mathrm{A}}(18)$ & $12.2 \pm 0.8^{\mathrm{A}}(22)$ & $21.5 \pm 1.4^{\mathrm{A}}(28)$ & $23.0 \pm 2.1^{\mathrm{A}}(10)$ \\
\hline 0.001 & $20.9 \pm 1.6^{\mathrm{A}}(18)$ & $15.3 \pm 1.5^{\mathrm{A}}(11)$ & $26.5 \pm 1.6^{\mathrm{A}}(36)$ & $50.1 \pm 4.0^{\mathrm{B}}(10)$ \\
\hline 0.01 & $36.2 \pm 1.5^{\mathrm{B}}(25)$ & $54.5 \pm 5.8^{\mathrm{B}}(20)$ & $32.6 \pm 2.6^{\mathrm{B}}(28)$ & $45.1 \pm 3.8^{\mathrm{B}}(10)$ \\
\hline 0.1 & $32.3 \pm 1.4^{\mathrm{B}}(24)$ & $44.4 \pm 3.5^{\mathrm{B}}(10)$ & $38.3 \pm 3.2^{\mathrm{B}}(24)$ & $46.6 \pm 4.2^{\mathrm{B}}(10)$ \\
\hline 1.0 & $34.7 \pm 1.6^{\mathrm{B}}(18)$ & $41.5 \pm 5.1^{\mathrm{B}}(6)$ & $30.0 \pm 1.8^{\mathrm{A}}(28)$ & $54.1 \pm 5.4^{\mathrm{B}}(10)$ \\
\hline 10.0 & $17.5 \pm 1.3^{\mathrm{A}}(21)$ & $20.0 \pm 2.4^{\mathrm{A}}(8)$ & $18.0 \pm 1.5^{\mathrm{A}}(21)$ & $30.1 \pm 6.8^{\mathrm{A}}(8)$ \\
\hline Prog 0 & $17.2 \pm 0.9^{\mathrm{A}}(18)$ & $12.6 \pm 0.6^{\mathrm{A}}(46)$ & $21.9 \pm 1.0^{\mathrm{A}}(10)$ & $23.0 \pm 2.1^{\mathrm{A}}(10)$ \\
\hline 125 & $31.3 \pm 2.1^{\mathrm{B}}(22)$ & $13.4 \pm 1.6^{\mathrm{A}}(8)$ & $45.6 \pm 4.4^{\mathrm{B}}(12)$ & $20.0 \pm 2.0^{\mathrm{A}}(8)$ \\
\hline 250 & $31.9 \pm 2.1^{\mathrm{B}}(20)$ & $21.2 \pm 1.7^{\mathrm{B}}(46)$ & $70.5 \pm 3.4^{\mathrm{B}}(10)$ & $23.7 \pm 4.4^{\mathrm{A}}(7)$ \\
\hline 500 & $39.6 \pm 1.9^{\mathrm{B}}(14)$ & $31.1 \pm 2.4^{\mathrm{B}}(43)$ & $102.6 \pm 10.2^{\mathrm{B}}(9)$ & $30.3 \pm 3.6^{\mathrm{A}}(10)$ \\
\hline 1000 & $40.6 \pm 2.4^{\mathrm{B}}(14)$ & $32.4 \pm 2.0^{\mathrm{B}}(38)$ & $124.4 \pm 7.8^{\mathrm{B}}(9)$ & $36.4 \pm 4.4^{\mathrm{A}}(7)$ \\
\hline Prog 500 & $37.9 \pm 2.2^{\mathrm{A}}(16)$ & $32.0 \pm 3.0^{\mathrm{A}}(21)$ & $74.5 \pm 5.9^{\mathrm{A}}(26)$ & $28.3 \pm 1.5^{\mathrm{A}}(30)$ \\
\hline Prog + E 0.001 & $31.4 \pm 1.4^{\mathrm{A}}(22)$ & $33.6 \pm 1.9^{\mathrm{A}}(9)$ & $62.6 \pm 6.2^{\mathrm{A}}(36)$ & $53.7 \pm 4.4^{\mathrm{A}}(10)$ \\
\hline 0.01 & $34.3 \pm 1.5^{\mathrm{A}}(18)$ & $51.7 \pm 3.0^{\mathrm{B}}(28)$ & $110.2 \pm 13.3^{\mathrm{A}}(33)$ & $88.6 \pm 6.8^{\mathrm{B}}(16)$ \\
\hline 0.1 & $40.1 \pm 2.3^{\mathrm{A}}(18)$ & $49.3 \pm 2.9^{\mathrm{B}}(18)$ & $127.1 \pm 8.3^{\mathrm{B}}(30)$ & $103.0 \pm 8.5^{\mathrm{B}}(22)$ \\
\hline 1.0 & $34.9 \pm 1.7^{\mathrm{A}}(20)$ & $48.8 \pm 3.4^{\mathrm{B}}(12)$ & $103.3 \pm 9.5^{\mathrm{A}}(30)$ & $127.9 \pm 7.9^{\mathrm{BC}}(12)$ \\
\hline 10.0 & $33.1 \pm 2.3^{\mathrm{A}}(14)$ & $39.1 \pm 3.0^{\mathrm{A}}(9)$ & $70.3 \pm 7.6^{\mathrm{A}}(16)$ & $72.6 \pm 5.6^{\mathrm{BD}}(12)$ \\
\hline
\end{tabular}

Young intact (18 days of age) and adult OV-X (ovariectomy at 22-24 days of age) females received subcutaneous injections of $50 \mu \mathrm{l}$ vehicle $(0-$ control $)$ or hormones daily for 10 days. Values are means \pm S.E.M. Differences between values for different doses of hormones were determined by one-way ANOVA followed by the Bonferroni test. Values within a column which do not have the same upper case superscript $(A, B)$ differ significantly $(P<0.05)$ from the respective vehicle-treated control group (E alone treated or Prog alone treated animals) or from the Prog treated animals (E plus Prog treated animals). Numbers in parentheses indicate the number of the first inguinal mammary glands.

Fig. 1 (Plate I) illustrates typical whole mounts of the first inguinal mammary glands of young intact females (day 28 of age) treated with placebo or with different doses of E. Glands of placebo treated animals contained ducts branched four to five times to form secondary, tertiary and quarternary ducts. All the ducts at the extremities of the glandular tree terminated in large dilated club-shaped TEBs. TEBs in the center of the gland and near the nipple were smaller. The duct system of adult OV-X females was similar to that in young intact 
prepubertal females with exception of TEBs that were rudimentary or absent as they regressed. Glands of E-treated animals showed a progressive lengthening and branching of ducts and the significant increase in the number of TEBs was observed in animals injected 0.01-1.0 $\mu \mathrm{g} . \mathrm{d}^{-1}$ of E or EV in young intact and adult OV-X females. Expansions of duct ends ranged in size from large TEBs (club-ends), generally at the periphery of the parenchymal area, to small TEBs throughout the parenchymal area. However, high doses of E or EV (1-10 $\left.\mu \mathrm{g} \cdot{ }^{\mathrm{d}-1}\right)$ had the opposite effect (inverted-U-shaped dose-response curve) (Table 1,3).

Table 2

Effect of $17 ß$ estradiol (E), progesterone (Prog) and their combinations on the number of terminal end buds (TEBs) and ductal branchings of the first inguinal mammary gland in young intact and adult castrated male mice

\begin{tabular}{|c|c|c|c|c|}
\hline \multirow[t]{2}{*}{$\begin{array}{l}\text { Hormonal } \\
\text { treatment }\left(\mu \mathrm{g} \cdot \mathrm{d}^{-1}\right)\end{array}$} & \multicolumn{2}{|c|}{ Number of TEBs } & \multicolumn{2}{|c|}{$\begin{array}{c}\text { Number of ductal } \\
\text { branchings }\end{array}$} \\
\hline & Intact & Castrated & Intact & Castrated \\
\hline 0 & $0.0 \pm 0.0^{\mathrm{A}}(15)$ & $0.0 \pm 0.0^{\mathrm{A}}(12)$ & $2.1 \pm 0.2^{\mathrm{A}}(25)$ & $2.7 \pm 0.3^{\mathrm{A}}(18)$ \\
\hline 0.001 & $0.4 \pm 0.2^{\mathrm{A}}(29)$ & $1.2 \pm 0.4^{\mathrm{A}}(13)$ & $2.4 \pm 0.2^{\mathrm{A}}(35)$ & $2.4 \pm 0.5^{\mathrm{A}}(18)$ \\
\hline 0.01 & $5.9 \pm 0.5^{\mathrm{B}}(48)$ & $7.7 \pm 0.6^{\mathrm{B}}(42)$ & $5.3 \pm 0.6^{\mathrm{B}}(26)$ & $6.2 \pm 0.7^{\mathrm{A}}(18)$ \\
\hline 0.1 & $14.6 \pm 0.9^{\mathrm{BC}}(46)$ & $11.1 \pm 1.3^{\mathrm{BC}}(19)$ & $18.1 \pm 1.2^{\mathrm{B}}(25)$ & $13.8 \pm 1.5^{\mathrm{B}}(18)$ \\
\hline 1.0 & $10.2 \pm 0.8^{\mathrm{BDE}}(28)$ & $9.9 \pm 1.9^{\mathrm{BCE}}(14)$ & $11.5 \pm 1.0^{\mathrm{B}}(28)$ & $12.9 \pm 3.3^{\mathrm{B}}(14)$ \\
\hline 10.0 & $4.3 \pm 0.6^{\mathrm{BDF}}(19)$ & $2.5 \pm 0.6^{\mathrm{ADF}}(17)$ & $5.3 \pm 0.8^{\mathrm{A}}(19)$ & $4.0 \pm 0.6^{\mathrm{A}}(19)$ \\
\hline Prog 0 & $0.0 \pm 0.0^{\mathrm{A}}(10)$ & $0.0 \pm 0.0^{\mathrm{A}}(6)$ & $2.1 \pm 0.4^{\mathrm{A}}(10)$ & $1.7 \pm 0.3^{\mathrm{A}}(6)$ \\
\hline 125 & $0.1 \pm 0.1^{\mathrm{A}}(9)$ & $0.0 \pm 0.0^{\mathrm{A}}(12)$ & $1.5 \pm 0.3^{\mathrm{A}}(8)$ & $1.5 \pm 0.2^{\mathrm{A}}(12)$ \\
\hline 250 & $0.2 \pm 0.2^{\mathrm{A}}(14)$ & $0.0 \pm 0.0^{\mathrm{A}}(20)$ & $2.2 \pm 0.5^{\mathrm{A}}(14)$ & $2.4 \pm 0.5^{\mathrm{A}}(20)$ \\
\hline 500 & $1.6 \pm 0.5^{\mathrm{A}}(29)$ & $0.0 \pm 0.0^{\mathrm{A}}(18)$ & $2.2 \pm 0.7^{\mathrm{A}}(10)$ & $1.5 \pm 0.2^{\mathrm{A}}(18)$ \\
\hline 1000 & $2.5 \pm 0.4^{\mathrm{B}}(38)$ & $0.0 \pm 0.0^{\mathrm{A}}(21)$ & $1.9 \pm 0.8^{\mathrm{A}}(10)$ & $1.3 \pm 0.1^{\mathrm{A}}(21)$ \\
\hline Prog 500 & $1.6 \pm 0.5^{\mathrm{A}}(29)$ & $0.0 \pm 0.0^{\mathrm{A}}(10)$ & $4.9 \pm 0.8^{\mathrm{A}}(27)$ & $3.9 \pm 0.6^{\mathrm{A}}(10)$ \\
\hline Prog + E 0.001 & $9.4 \pm 1.2^{\mathrm{A}}(21)$ & $4.1 \pm 1.5^{\mathrm{A}}(10)$ & $16.2 \pm 2.6^{\mathrm{A}}(23)$ & $5.6 \pm 1.5^{\mathrm{A}}(10)$ \\
\hline 0.01 & $36.7 \pm 2.7^{\mathrm{BC}}(45)$ & $32.8 \pm 1.7^{\mathrm{BC}}(10)$ & $105.8 \pm 10.1^{\mathrm{BC}}(30)$ & $78.6 \pm 9.0^{\mathrm{BC}}(10)$ \\
\hline 0.1 & $46.0 \pm 3.3^{\mathrm{BCE}}(29)$ & $43.0 \pm 3.2^{\mathrm{BCE}}(6)$ & $152.0 \pm 8.6^{\mathrm{BDE}}(30)$ & $125.7 \pm 9.8^{\mathrm{BDE}_{(}(6)}$ \\
\hline 1.0 & $35.5 \pm 3.2^{\mathrm{BCEG}}(26)$ & $47.3 \pm 4.4^{\mathrm{BDEG}}(6)$ & $150.5 \pm 8.6^{\mathrm{BDEG}}(25)$ & $89.6 \pm 9.3^{\mathrm{BCFG}}(7)$ \\
\hline 10.0 & $22.8 \pm 1.5^{\mathrm{BDFH}}(23)$ & $31.5 \pm 2.8^{\mathrm{BCFH}}(8)$ & $59.9 \pm 5.5^{\mathrm{BDFH}}(23)$ & $92.1 \pm 8.6^{\mathrm{BCEH}_{(}}(8)$ \\
\hline
\end{tabular}

Young intact (18 days of age) and adult castrated males of $\mathrm{C} 3 \mathrm{H}$ strain were subcutaneously injected $50 \mu \mathrm{l}$ of vehicle $(0-$ control $)$ or a steroid hormone daily for 15 days. Other details are in the legend to Table 1.

Mammary glands of placebo treated males, both intact (35 days of age) and castrated (adult), showed no TEBs and no indication of branching of ducts beyond rudimentary duct system typical of untreated $\mathrm{C} 3 \mathrm{H}$ males. Rudiment of the first inguinal mammary gland from both young intact and adult castrated $\mathrm{C} 3 \mathrm{H}$ males is similar to that in a 13- to 14-day-old female fetus (Raynaud 1961). Glands of E- or EV-treated males showed appearance and increasing number of TEBs and progressive growth and branching of ducts from dose 0.01$0.1 \mu \mathrm{g} . \mathrm{d}^{-1}$ of E. High dose of $\mathrm{E}$ or EV $\left(10 \mu \mathrm{g} . \mathrm{d}^{-1}\right)$ decreased both the number of TEBs and branchings of ducts (Table 2). In young intact female and male mice treated with EV at a maximum effective dose $\left(0.1 \mu \mathrm{g} . \mathrm{d}^{-1}\right)$ a higher number of TEBs was achieved than in animals treated with E. Photographs of whole mounts of the first inguinal mammary glands of young intact and adult castrated males treated with E or E plus Prog were presented in our earlier paper ( $\breve{k} k$ arda 2002a).

To assess the contribution of progestational compounds to mammary gland growth, we analyzed whole-mounts of mammary glands from intact and gonadectomized mice treated with Prog alone or with Prog plus E. In young intact females Prog alone increased both the 
Table 3

Effect of estradiol valerate (EV) on the number of terminal end buds (TEBs) and ductal branchings of the first inguinal mammary gland of young intact and adult gonadectomized female and male mice

\begin{tabular}{|c|c|c|c|c|}
\hline $\begin{array}{l}\text { Hormonal } \\
\text { treatment }\left(\mu \mathrm{g} . \mathrm{d}^{-1}\right)\end{array}$ & \multicolumn{2}{|c|}{ Number of TEBs } & \multicolumn{2}{c|}{$\begin{array}{c}\text { Number of ductal } \\
\text { branchings }\end{array}$} \\
\hline FEMALES & Intact & OV-X & Intact & OV-X \\
\hline EV 0 & $15.6 \pm 1.5^{\mathrm{A}}(8)$ & - & $20.9 \pm 1.8^{\mathrm{A}}(10)$ & - \\
\hline 0.001 & $23.2 \pm 2.2^{\mathrm{A}}(10)$ & - & $26.8 \pm 2.5^{\mathrm{A}}(10)$ & - \\
\hline 0.01 & $25.1 \pm 1.6^{\mathrm{B}}(10)$ & - & $29.7 \pm 1.7^{\mathrm{A}}(9)$ & - \\
\hline 0.1 & $41.8 \pm 2.1^{\mathrm{B}}(12)$ & - & $42.0 \pm 2.2^{\mathrm{B}}(12)$ & - \\
\hline 1.0 & $26.6 \pm 1.3^{\mathrm{B}}(10)$ & - & $21.8 \pm 1.6^{\mathrm{A}}(10)$ & - \\
\hline 10.0 & $17.6 \pm 1.9^{\mathrm{A}}(10)$ & - & $19.0 \pm 2.1^{\mathrm{A}}(10)$ & - \\
\hline \multicolumn{5}{|c|}{} \\
\hline MALES & Intact & Castrated & Intact & Castrated \\
\hline 0 & $0.0 \pm 0.0^{\mathrm{A}}(10)$ & $0.0 \pm 0.0^{\mathrm{A}}(12)$ & $2.0 \pm 0.4^{\mathrm{A}}(7)$ & $1.9 \pm 0.3^{\mathrm{A}}(14)$ \\
\hline 0.001 & $2.8 \pm 0.7^{\mathrm{A}}(9)$ & $0.5 \pm 0.2^{\mathrm{A}}(17)$ & $2.0 \pm 0.5^{\mathrm{A}}(10)$ & $2.1 \pm 0.4^{\mathrm{A}}(16)$ \\
\hline 0.01 & $10.2 \pm 1.2^{\mathrm{A}}(10)$ & $4.2 \pm 0.9^{\mathrm{A}}(17)$ & $13.0 \pm 1.8^{\mathrm{B}}(9)$ & $3.6 \pm 0.6^{\mathrm{A}}(18)$ \\
\hline 0.1 & $39.6 \pm 6.6^{\mathrm{B}}(10)$ & $14.4 \pm 1.6^{\mathrm{B}}(20)$ & $42.4 \pm 4.9^{\mathrm{B}}(8)$ & $21.9 \pm 2.8^{\mathrm{B}}(17)$ \\
\hline 1.0 & $6.3 \pm 1.1^{\mathrm{A}}(8)$ & $7.1 \pm 0.9^{\mathrm{B}}(18)$ & $5.9 \pm 1.6^{\mathrm{A}}(10)$ & $8.8 \pm 1.0^{\mathrm{B}}(15)$ \\
\hline 10.0 & $3.1 \pm 0.4^{\mathrm{A}}(8)$ & $3.5 \pm 0.7^{\mathrm{A}}(17)$ & $2.9 \pm 0.2^{\mathrm{A}}(8)$ & $3.9 \pm 0.7^{\mathrm{A}}(18)$ \\
\hline
\end{tabular}

Other details are in the legend to Table 1

number of TEBs and the degree of ductal branching from dose $125 \mu \mathrm{g} \cdot \mathrm{d}^{-1}$ (Table 1). The number of TEBs increased from 17.2 \pm 0.9 in controls to $31.3 \pm 2.1$ and the number of ductal branchings increased from $21.9 \pm 1.0$ in controls to $45.6 \pm 4.4$. Higher dose of Prog $\left(250 \mu \mathrm{g} . \mathrm{d}^{-1}\right)$ induced formation of alveolar buds and lobuloalveolar structure in the center of the gland and at the dose of $500 \mu \mathrm{g} . \mathrm{d}^{-1}$ the number of lateral branches with alveolar buds were numerous along the sides of large mammary ducts (Table 1, Fig. 2). The maximal growth response was observed in animals treated with $1000 \mu \mathrm{g} . \mathrm{d}^{-1}$ of Prog: the number of branches was $124.4 \pm 7.8$. However, in adult OV-X females, Prog alone stimulated growth of only small TEBs from the dose of $250 \mu \mathrm{g} . \mathrm{d}^{-1}$ but the increase in ductal branching was not significant.

Prog alone at high dose $\left(1000 \mu \mathrm{g} . \mathrm{d}^{-1}\right)$ only slightly increased number of TEBs in young intact males but had no effect on number of both TEBs in castrated animals and ductal branchings in young intact and castrated males (Table 2).

In both young intact and adult gonadectomized male and female mice treated simultaneously with E and Prog, a more complex epithelial network with numerous TEBs, ductal branches and lobuloalveolar structures was formed. In female mice moderate doses of E acted synergistically with Prog to produce a higher mammary growth rate (side branching of the ducts and formation of lobuloalveolar structures) than that observed in young intact females which had received injections of $\mathrm{E}$ alone or in adult OV-X females treated with Prog alone or E alone (Table 1, Plate II, Fig 2). In young intact females treated with E+Prog, the number of TEBs and the number of ductal branchings was not significantly different from that in animals treated with Prog alone. However, in OV-X females a combination of E plus Prog significantly increased the number of both TEBs and ductal branchings when compared with OV-X females treated with Prog alone. The number of TEBs increased from 32.0 \pm 3.0 in animals treated with Prog alone to 51.7 \pm 3.0 in these treated with E plus Prog; the number of ductal branchings increased from $28.3 \pm 1.5$ to $127.9 \pm 7.9$.

In males $E$ also synergized the effect of Prog in stimulation of both the number of TEBs and the number of ductal branchings. The maximum effective dose of $\mathrm{E}\left(0.1 \mu \mathrm{g} . \mathrm{d}^{-1}\right)$ in intact animals treated simultaneously with Prog increased number of TEBs to $46.0 \pm 3.3$ from 1.6 \pm 0.5 in animals treated with Prog alone or from $14.6 \pm 1.0$ in animals treated with $E$ alone; 
the number of ductal branchings increased to $152.0 \pm 8.6$ from $4.9 \pm 0.8$ in animals treated with Prog alone or from $18.1 \pm 1.2$ in animals treated with E alone. Similar synergism between $\mathrm{E}$ and Prog was also seen in adult castrated males (Table 2).

High dose $\left(10 \mu \mathrm{g} . \mathrm{d}^{-1}\right)$ of $\mathrm{E}$ in combination with Prog decreased both the number of TEBs and ductal branchings in males (Table 2). In young intact females the number of ductal branchings was decreased but the number of TEBs was not affected. In OV-X females the number of TEBs was decreased but the number of ductal branchings was not significantly decreased by high dose of $\mathrm{E}$ (Table 1).

In male mice $E$ synergized the effect of Prog in stimulation of both number of TEBs and number of ductal branchings. The maximum effective dose of $E\left(0.1 \mu \mathrm{g} . \mathrm{d}^{-1}\right)$ in the presence of Prog increased number of TEBs to $46.0 \pm 3.3$ from $1.6 \pm 0.5$ in the presence of Prog alone or from $14.6 \pm 1.0$ in the presence of $E$ alone in young intact males. Results obtained with adult castrated animals were similar to those with young intact males. High dose $\left(10 \mu \mathrm{g} . \mathrm{d}^{-1}\right)$ of estradiol significantly decreased number of TEBs even in the presence of Prog, however, the number of TEBs was still significantly higher than in controls (Table 2).

Fig. 2 (Plate II) shows the effect of different doses $\left(125-1000 \mu \mathrm{g} . \mathrm{d}^{-1}\right)$ of Prog and a combination of Prog $\left(500 \mu \mathrm{g} . \mathrm{d}^{-1}\right)$ and different doses $\left(0.001-10 \mu \mathrm{g} . \mathrm{d}^{-1}\right)$ of $E$ on the duct length, the number of ductal branchings and the formation of lobuloalveolar structures in young intact females. Glands of Prog treated animals showed a progressive increase in the number of TEBs and progressive lengthening and branching of ducts from the dose of 125 $\mu \mathrm{g} . \mathrm{d}^{-1}$, the formation of lobuloalveolar structures appeared from the dose of $250 \mu \mathrm{g} . \mathrm{d}^{-1}$, and the maximal growth response was observed in animals treated with $1000 \mu \mathrm{g} . \mathrm{d}^{-1}$ of Prog and reached higher level than that achieved in animals treated with $\mathrm{E}$ alone. The number of both small and large TEBs increased from control level 17.2 \pm 0.9 to $40.6 \pm 2.4$ and number of ductal branchings increased from $21.9+1.0$ to $124.4 \pm 7.8$ in young intact females. However, in adult $\mathrm{OV}-\mathrm{X}$ females Prog increased number of small TEBs only from $12.6 \pm 0.6$ to 32.4 \pm 2.0 but the increase of ductal branching was not significant. Both parameters were lower than those achieved in OV-X animals treated with E alone (Table 1). In males, Prog alone in high $\left(1000 \mu \mathrm{g} . \mathrm{d}^{-1}\right)$ dose increased number of TEBs only slightly (from 0.0 to 2.5 in Progtreated animals) in young intact males, but had no effect on the number of TEBs in adult castrated males and on the number of ductal branchings in both young intact and adult castrated males (Table 2).

In both young intact and adult gonadectomized males and $\mathrm{OV}-\mathrm{X}$ female mice treated with $500 \mu \mathrm{g} . \mathrm{d}^{-1}$ Prog and different doses of E $\left(0.001-1 \mu \mathrm{g} . \mathrm{d}^{-1}\right) \mathrm{E}$ acted synergistically with Prog to produce higher duct branching (side branching of the ducts and formation of lobuloalveolar structures) than that observed in animals which had received injections of either Prog alone or E alone. However, in young intact females treated with different doses of E plus Prog the number of both TEBs and ductal branchings was not significantly different from that in animals treated with Prog alone. In contrast, even in the presence of Prog the very high dose $\left(10 \mu \mathrm{g} \cdot \mathrm{d}^{-1}\right)$ of E decreased number of both TEBs and ductal branchings in males and OV-X females.

\section{Discussion}

Most tissues and organs undergo massive growth in the early stages of development, i.e. during fetal and early postnatal life. By contrast, mammary gland is a unique organ that undergoes most of its development during puberty and after the animal has reached maturity, that is, following the onset of pregnancy and lactation. In prepubertal and pubertal period of postnatal life the epithelium of mouse mammary gland expands and invades the mammary fat pad by branching morphogenesis (B orellini and Oka 1989; Richert et al. 2000). The primary epithelial structures in mammary glands at the start of ductal growth are TEBs, 
which appear in $\mathrm{C} 3 \mathrm{H}$ mice between 15 to 20 days of age, i.e. well before puberty (the onset of estrous cycling) and reach their maximal numbers at 40 days of age. In mice older, the numbers of TEBs decreased (Köhlerová and Škarda, unpublished results). When the TEBs reach the connective tissue capsule at the edge of the fat pad at 10-12 weeks of age, they regress to form terminal ducts (B orellini and Oka 1989; Richert et al. 2000).

The morphometric criteria of mammary growth as the number of ductal branchings and the number of end buds were successfully used in an experiment designed to study the effect of dietary fats on normal growth of the mammary gland in female mice (Nishinakagaw a et al. 1989). The present results demonstrated that these criteria are also suitable quantitative parameters for bioassay of estrogenicity both in female and male mice. E alone evoked limited formation of TEBs and lengthening and branching of mammary ducts in intact prepubertal and adult gonadectomized male and female mice similarly as it was demonstrated for percent area of mammary fat pad occupied by mammary epithelial structures (Š karda $2002 \mathrm{ab}$ ).

It is interesting to note that although the number of TEBs per gland appears to be similar in the virgin intact (17.2 - 18.3) and the virgin OV-X animals (12.2 - 12.6) the glands of intact females have far greater size of TEBs than the tissue of OV-X females. This is due to the fact that there is an extensive proliferation of epithelial cells between 20 to 28 days of age in intact animals and ovariectomy performed at this age results only in regression of duct and TEBs diameter but these structures are still present. TEBs are visible as slightly dilated and darker ends of some ducts. The higher number of TEBs in animals treated with EV than in those treated with E could be explained by lower toxicity of EV due to its slower release from the injection site into general circulation and/or its slower tissue uptake.

In prepubertal females, Prog alone stimulated growth of mammary epithelial structures more than $\mathrm{E}$ alone. This could be related to secretion of estrogens in immature ovaries in amounts that are sufficient to synergize with injected Prog in stimulation of mammary growth. This interpretation is in agreement with decreased ability of Prog to stimulate mammary growth in ovariectomized animals. Moreover, Prog alone stimulated mammary growth only slightly in young intact and had no effect on mammary growth in adult castrated males. A slight stimulation of mammary growth in young intact animals by high doses of Prog alone could be related to the capacity of Leydig cells to convert testosterone by aromatase (the enzyme that catalyzes the synthesis of endogenous estrogen from testosterone) to E in males (Aking beni et al. 2003) and to ability of high doses of Prog to decrease a threshold of estrogen action in mammary gland of females. The number of TEBs and ductal branchings showed a distinct biphasic response to the application of E. E doses of 0.001 to $1.0 \mu \mathrm{g} . \mathrm{d}^{-1}$ stimulated mammary growth, but dose above $10 \mu \mathrm{g} . \mathrm{d}^{-1}$ was inhibitory. The highest dose $\left(10 \mu \mathrm{g} . \mathrm{d}^{-1}\right)$ of $\mathrm{E}$ was completely devoid of effect not only on the number of both TEBs and ductal branchings (present results) but also on the \% area of mammary fat pad occupied by mammary epithelial structures in females and adult castrated males (Šk arda 2002ab). Due to this inverted U-shaped dose-response curve of estrogens, testing with several doses should be used. Potential mechanisms mediating the reduction in mammary gland growth may include receptor down regulation and the capacity for estrogens to bind to receptors for other steroid hormones, androgen or glucocorticoid receptors, resulting in antagonistic effects mediated via other receptor systems in response to supraphysiological doses of estrogens (vom Saal et al. 1997). This interpretation is further supported by inhibitory action of both testosterone and cortisol on E or E plus Prog or norethindrone (a synthetic derivative of 19-nortestosterone exhibiting progestational and estrogenic activities) stimulated mammary growth ( $\breve{S} \mathrm{karda} 2002 \mathrm{abc}$ ).

Diverse animal models and assays have been used to measure estrogenicity. However, all changes in endocrine-sensitive tissues are not necessarily specific e.g. both rodent 
uterotrophic and human breast cancer cell line MCF-7 assays lack specificity as estrogens and androgens both enhanced uterine growth and MCF-7 cell proliferation (Ne u mann and Steinbeck 1974; Lippman et al. 1976). These stimulatory, estrogen-like effects of androgens are correlated with the binding of these steroids to the estrogen receptors and are considered as an estrogen receptor mediated mechanism (Hackenberg et al. 1993). Therefore, it is important that testing for estrogenicity potential includes the ability to detect androgenic and antiandrogenic activities. This can be done by measuring the increase in seminal vesicle weight and by the decrease in E or E plus Prog or norethindrone stimulated mammary growth and abolition of testosterone effect in seminal vesicles, uterus and mammary gland by antiandrogens (Šk arda 2002abc, 2003).

In conclusion, our results demonstrated that the number of TEBs and the degree of ductal branching are good parameters for estrogenicity testing. The disadvantage of estrogenicity bioassay on the female mammary gland is the stimulation of growth of mammary epithelial structures in intact animals not only by estrogen alone but also by Prog alone. This disadvantage was substantially eliminated by the use of OV-X females and young intact and adult castrated males. In these animals Prog alone has very low or no stimulatory effect on the number of both TEBs and ductal branchings. Agreement in results between the number of both TEBs and ductal branchings on the one side (present results) and the percent area of mammary fat pad occupied by mammary epithelial structures ( $\breve{k} k$ arda 2002ab) on the other side is good over the wide range of mammary growth and development. However, the counting of ductal branchings is not so rapid as determination of a percent area of epithelial structures in fat pad particularly in mammary glands with very advanced growth and development as it is seen in animals treated with E plus Prog.

\section{Počet terminálních pupenů a stupeň větvení duktů jako morfometrické parametry při biostanovení aktivit agonistů a antagonistů steroidních hormonů}

Dřívěǰši práce demonstrovaly, že procento plochy, které zaujímají epiteliální struktury v tukové tkáni mléčné žlázy je vhodným parametrem pro biostanovení estrogenicity a pro stanovení směsi agonistů a antagonistů estrogenů. Cílem této práce bylo zjistit, jak estradiol (E), progesteron (Prog) a E plus Prog v závislosti na dávce ovlivňují počet terminálních pupenů (TEBs) a stupeň větvení duktů u mladých intaktních (18 dní věku) a dospělých gonadektomizovaných samcủ a samic (ovariektomovaných mezi 21.-24. dnem věku; OV$\mathrm{X})$ myší a zda jsou tyto parametry vhodné pro biostanovení estrogenicity. U zvírat ošetřených $\mathrm{E}$ nebo $\mathrm{E}$ valerátem (EV) byla získána klasická bifázická kř̌ivka mezi dávkou a odpovědí. Střední dávky E nebo EV $\left(0,001-0,1 \mu \mathrm{g} \cdot \mathrm{d}^{-1}\right)$ zvýšily jak počet TEBs (hlavně velkých pupenů), tak větvení duktů, zatímco vysoké dávky $\left(1 \mathrm{a} 10 \mu \mathrm{g} \cdot \mathrm{d}^{-1}\right)$ byly inhibiční. U mladých intaktních samic samotný Prog od dávky $125 \mu \mathrm{g} . \mathrm{d}^{-1}$ zvyšoval jak počet TEBs, tak větvení duktů tak, že byla dosažena vyšší úroveň než u zviřat ošetřených samotným E; u dospělých OV-X samic zvyšoval samotný Prog od dávky $250 \mu \mathrm{g} \cdot \mathrm{d}^{-1}$ počet jen malých TEBs, a to na úroveň nižší než u zviŕat ošetřených samotným E. U mladých intaktních samců byl zaznamenán nízký vzestup TEBs (malých pupenů), a to pouze př̀i vysoké dávce Prog $\left(1000 \mu \mathrm{g} . \mathrm{d}^{-1}\right)$; u dospělých kastrovaných samců Prog neovlivnil ani počet TEBs ani větvení duktů. U mladých intaktních samic ošetřených střední dávkou $\left(0,001-0,1 \mu \mathrm{g} \cdot \mathrm{d}^{-1}\right)$ E plus Prog $\left(500 \mu \mathrm{g} \cdot \mathrm{d}^{-1}\right)$ se ani počet TEBs ani stupeň větvení duktů signifikantně nelišily od počtů těchto struktur u intaktních samic ošetřených samotným Prog. Naproti tomu u OV-X samic ošetřených E plus Prog byl jak počet TEBs, tak počet větvení duktů výrazně vyšší než $\mathrm{u}$ zviŕ̌at ošetřených samotným Prog. $\mathrm{V}$ mléčné žláze samců také působil $\mathrm{E}$ synergisticky $\mathrm{s}$ Prog, takže počet Tebs a větvení duktů byl vyšší než u zviŕat ošetř̛ených samotným E nebo Prog. Vysoká dávka $\left(10 \mu \mathrm{g} \cdot \mathrm{d}^{-1}\right)$ E v kombinaci s Prog zvy̌šila jak počet TEBs, tak větvení duktů u samců a OV-X samic. 


\section{Acknowledgements}

We are grateful to Eva Urbanová for her excellent technical assistance and to Professor Evelyn M. Rivera, Michigan State University, East Lansing, U.S.A. for gift of heavy duty Kapak pouches. This work was funded by the Grant Agency of the Czech republic (project No. 524/02/0406) and the Academy of Sciences of the Czech Republic (project no. IBS5045302).

\section{References}

AKINGBENI B-T, GE R, ROSENFELD CS, NEWTON LG, HARDY DO, CATTERALL JF, LUBAHN DB, KORACH KS, HARDY MP 2003: Estrogen receptor- gene deficiency enhances androgen biosynthesis in the mouse Leydig cell. Endocrinology 144: 84-93

ANKLEY G, MIHARICH E, STAHL R, TILLIT D, COLBORN T, McMASTER, S, MILLER R, BANTLE J, CAMPBELL P, DENSLOW N, DICKERSON R, FOLMAR L, FRY M, GIESY J, GRAY LE, GUINEY P, HUTCHINSON T, KENNEDY S, KRAMER V, LeBLANC G, MAYES M, NIMROD A, PATINO R, PETERSON R, PURDY R, RINGER R, THOMAS P, TOUART L, van der KRAAK G, ZACHAREWSKI T 1998: Overview of a workshop on screening methods for detecting potential (anti-)estrogenic/androgenic chemicals in wildlife. Environ Toxicol Chem 17: 68-87

BORELLINI F, OKA T 1989: Growth control and differentiation in mammary epithelial cells. Environ Health Perspect 80: 85-99

CLARK JH, WATSON C, UPCHURCH S, PADYKULA H, MARKAVERICH B, HARDIN JW 1980: Estrogen action in normal and abnormal cell growth. In: McLACHLAN JA (Ed.): Estrogens in the Environment. New York, Elsevier, pp. 53-67

HACKENBERG R, TURGETTO I, FILMAR A, SCHULZ K-D 1993: Estrogen and androgen receptor mediated stimulation and inhibition of proliferation by androst-5-ene-3,17-diol in human mammary cancer cells. J Steroid Biochem Mol Biol 46: 597-603

KORACH KS, McLACHLAN JA 1995: Techniques for detection of estrogenicity. Environ Health Perspect 103 (Suppl 7): 5-8

LIPPMANN M, BOLAN G, HUFF K 1976: The effects of androgens and antiandrogens on hormone-responsive human breast cancer in long-term tissue culture. Cancer Res 36: 4610-4618

NEUMANN F, STEINBECK H 1974: VI. Antiandrogens. In: NEUMANN F (Ed.): Androgens II and Antiandrogens. Springer, Berlin, pp. 235-484

NISHINAKAGAWA H, FAULKIN LJ, MITCHELL DJ 1989: The effect of dietary fat on the mammary gland in immature mice. Jpn J Vet Sci 51: 447-449

PAYNE J, RAJAPAKSE N, WILKINS M, KORTENKAMP A 2000: Prediction and assessment of the effects of mixtures of four xenoestrogens. Environ Health Perspect 108: 983-987

RAYNAUD A 1961: Morphogenesis of the mammary gland. In: KON SK and COWIE AT (Eds.): Milk: The Mammary Gland and Its Secretion, New York; Academy Press, Vol. 1, pp. 3-46

RICHERT MM, SCHWERTFEGER KL, RYDER JW, ANDERSON SM 2000: An atlas of mouse mammary gland development. J Mammary Gland Biol Neoplasia 5: 227-241

ŠKARDA J 2001: Detection of estrogenicity by bioassay on the mouse mammary gland in vivo. Physiol Res 50: 275-282

ŠKARDA J 2002a: Sensitivity and specificity of the bioassay of estrogenicity in mammary gland and seminal vesicles of male mice. Physiol Res 51: 267-276

ŠKARDA J 2002b: Sensitivity and specificity of bioassay of estrogenicity on mammary gland and uterus of female mice. Physiol Res 51: 407-412

ŠKARDA J 2002c: Norethindrone acetate and testosterone interactions in the mammary gland, uterus and seminal vesicles of mice. Acta Vet Brno 71: 463-471

ŠKARDA J 2003: Bioassay of steroid hormone agonist and antagonist activities of antiandrogens on mammary gland, seminal vesicles and spleen of male mice. J Vet Med A, 50: 204-212

vom SAAL FS, TIMMS BG, MONTANO MM, PALANZA P, THAYER KA, NAGEL SC, DHAR MD, GANJAM VK, PARMIGIANI S, WELSHONS WV 1997: Prostate enlargement in mice due to fetal exposure to low doses of estradiol or diethylstilbestrol and opposite effects at high doses. Proc Natl Acad Sci USA 94: 2056-2061 
Plate I

Hufryi A. et al.: Number of terminal... pp. 483-491



Fig.1. Whole mounts of the first inguinal mammary glands of young intact females treated with different doses of $17 \beta$ estradiol (E) Prepubertal intact C3H/Di female mice were treated s.c. with different doses of $\mathrm{E}$ for 10 days. Treatment commenced on day 18 of age and all animals were killed on day 28. (A) Epithelial structures of placebo treated animal. The large arrow indicates the nipple region; small arrows indicate large terminal end buds (TEBs)- club end at the periphery; mammary glands from animals treated with $0.001 \mu \mathrm{g} . \mathrm{d}^{-1}(\mathrm{~B})$, $0.01 \mu \mathrm{g} . \mathrm{d}^{-1}(\mathrm{C}), 0.1 \mu \mathrm{g} \cdot \mathrm{d}^{-1}$ (D), $1.0 \mu \mathrm{g} \cdot \mathrm{d}^{-1}$ (E), 10.0 $\mu \mathrm{g} \cdot \mathrm{d}^{-1}$ (F) of E. Note a progressive lengthening and branching of ducts and the increasing number of TEBs (large TEBs-club ends at the periphery - arrow, small TEBs throughout the parenchymal area - arrowhead) from the dose $0.001 \mu \mathrm{g} . \mathrm{d}^{-1}$ to $0.01-0.1 \mu \mathrm{g} . \mathrm{d}^{-1}$ of E. The high doses (1.0 and $\left.10.0 \mu \mathrm{g} . \mathrm{d}^{-1}\right)$ had the opposite effect (inverted-U-shaped dose-response curve). 


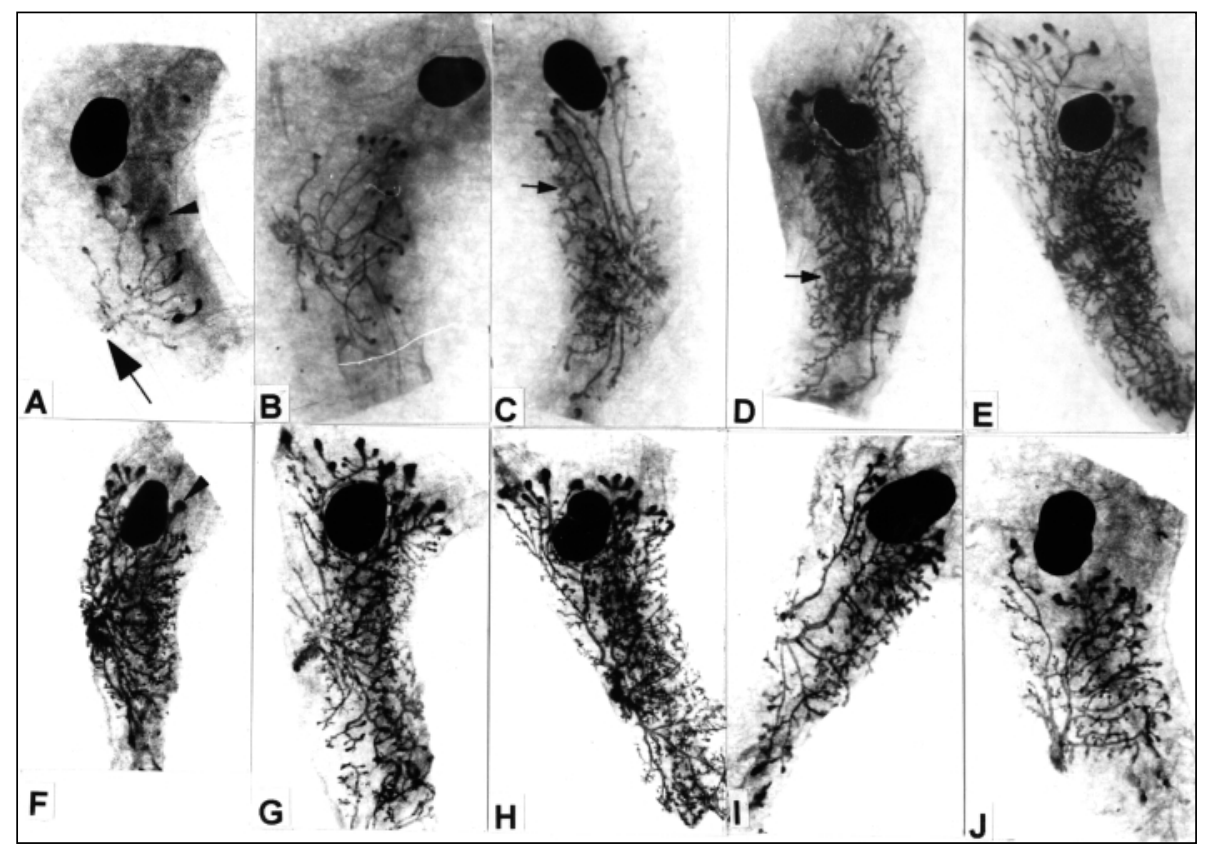

Fig. 2. Whole-mounts of the first inguinal mammary glands of young intact females treated with different doses of progesterone (Prog) alone or with Prog at dose $500 \mu \mathrm{g} . \mathrm{d}-1$ plus different doses of $17 \beta$ estradiol (E) (A) Epithelial structures of placebo treated animal. The large arrow indicates the nipple region; the arrowheads indicate TEBs. Mammary glands from animals treated with $125 \mu{\mathrm{g} . \mathrm{d}^{-1}}$ (B), $250 \mu \mathrm{g} \cdot \mathrm{d}^{-1}(\mathrm{C}), 500$ $\mu \mathrm{g} . \mathrm{d}^{-1}$ (D), $1000 \mu \mathrm{g} . \mathrm{d}^{-1}$ (E) of Prog. Note that the lengthening and branching of ducts continues to the highest dose of Prog. The number of TEBs significantly increased by Prog alone. The formation of lateral branches in animals treated with $250 \mu \mathrm{g} \cdot \mathrm{d}^{-1}$ and higher dose of Prog (arrow C) and alveolar buds (arrow D) in animals treated with $500 \mu \mathrm{g} . \mathrm{d}^{-1}$ and higher dose of Prog was clearly seen. Mammary glands from animals treated with Prog plus E $0.001 \mu \mathrm{g} . \mathrm{d}^{-1}(\mathrm{~F}), 0.01 \mu \mathrm{g} . \mathrm{d}^{-1}(\mathrm{G}), 0.1 \mu \mathrm{g} . \mathrm{d}^{-1}(\mathrm{H}), 1.0 \mu \mathrm{g} . \mathrm{d}^{-1}(\mathrm{I}), 10.0 \mu \mathrm{g} . \mathrm{d}^{-1}(\mathrm{~J})$. Note large numbers of TEBs and lateral branches and alveolar buds in combinations depicted under F, G, and $\mathrm{H}$ (Prog 500 plus E 0.001-0.1 $\left.\mu \mathrm{g} . \mathrm{d}^{-1}\right)$. At high doses of E, numbers of branches tended to decrease (Table 1). 